\title{
RESPON TERHADAP PEMBELAJARAN BLENDED LEARNING DI ERA PANDEMI COVID-19 DENGAN TINGKAT STRES MAHASISWA
}

\author{
Clara Cassandra Resubun ${ }^{1}$, Mizam Ari Kurniyanti ${ }^{2 *}$, Kurniawan Erman Wicaksono ${ }^{3}$ \\ $\mathbf{1 , 2 , 3}$ STIKES Widyagama Husada Malang
}

\begin{abstract}
Background: The Covid-19 pandemic has had such a huge impact on all aspects, including in the word of education. Education during the pandemic use blended learning of changes in the learning system, this causes stress to occur in students which affects student responses and the level of stress experienced during the covid 19 pandemic. Objective : to determine the e relationship between student responses to blended learning in the covid 19 pandemic era with the level of stress on 4th students of Stikes Widyagama Husada Malang. Method: This study uses a descriptive correctional research design with a cross sectional approach with a sample of 50 respondents who have been selected through a total sampling technique and data analysis using the Kendall's tau-b test. Results : The results of this study indicate that most of the respondents (40.0\%) showed a lack of response to blended learning and a small percentage (10.0\%) showed a good response to blended learning. There are 33 respondents who show stress in the category of severe stress $(66.0 \%)$ and 4 respondents who show mild stress $(8.0 \%)$. The result of p-value $0.000(<0.05)$ so that $\mathrm{H1}$ is accepted or significant. The results of the correlation of student responses to blended learning in the Covid 19 era with a stress level of 0.503 means that there is a strong and positive relationship between the two variables. Conclusion : there is a relationship between student responses to blended learning and stress levels in 4th semester nursing students Stikes Widyagama Husada Malang.
\end{abstract}

Keywords: Pandemic, Response, Blended Learning, Stress

\begin{abstract}
Abstrak
Latar Belakang : Pandemi covid 19 memberikan dampak yang begitu besar ke segala aspek termasuk dalam dunia pendidikan. Pendidikan pada masa pandemi menggunakan pembelajaran blended learning karena adanya perubahan sistem pembelajaran, menyebabkan terjadi stres pada mahasiswa yang mempengaruhi respon mahasiswa serta tingkat stres yang dialami selama pandemi covid 19. Tujuan: untuk mengetahui hubungan respon mahasiswa terhadap pembelajaran blended learning diera pandemi covid 19 dengan tingkat stres pada mahasiswa semester 4 Stikes Widyagama Husada Malang. Metode: Penelitian ini menggunakan desain penelitian deskriptif korelasi dengan pendekatan cross sectional dengan jumlah sampel 50 responden yang telah diseleksi melalui teknik sampling total sampling dan analisis data menggunakan uji Kendall's tau-b. Hasil: hasil penelitian ini menunjukan bahwa sebagian besar responden sebanyak $(40.0 \%)$ menunjukan kurangnya respon terhadap pembelajaran blended learning dan sebagian kecil sebanyak (10.0\%) menunjukan respon yang baik terhadap pembelajaran blended learning. Terdapat 33 responden yang menunjukan stres berkategori stres berat sebesar $(66.0 \%)$ dan 4 responden yang menunjukan stres ringan sebesar (8.0\%). Hasil uji Kendall's tau-b didapatkan pvalue $0.000(<0.05)$ sehingga di terima $\mathrm{H} 1$ diterima atau signifikan. Hasil korelasi respon mahasiswa terhadap pembelajaran blended learning diera covid 19 dengan tingkat stres sebesar 0.503 berarti terdapat hubungan yang kuat dan posisitif antara kedua variabel. Kesimpulan: Ada hubungan respon mahasiswa terhadap pembelajaran blended learning dengan tingkat stres pada mahasiswa keperawatan semester 4 Stikes Widyagama Husada Malang.
\end{abstract}

Kata Kunci: Pandemi, Respon, Blended Learning, Stres 


\section{PENDAHULUAN}

COVID-19 merupakan penyakit Coronavirus (COVID-19) 2019 yang menyebar secara global termasuk di indonesia. Covid-19 merupakan penyakit yang menyerang sistem respirasi. Hal ini dapat menimbulkan sistem penyebaran penyakit terus menerus menjadi luas (Ifdil, 2020). Pandemi covid-19 ini sangat mempengaruhi dalam bermacam aspek kehidupan dari segi ekonomi, sosial, pendidikan serta psikologis warga. Berbagai macam cara sudah dicoba untuk menghindari terjadi penyebaran serta menekan meningkatnya prevalensi covid-19 dan kematian. Salah satunya adalah penerapan kebijakan Pembatasan sosial Berskala Besar ( PSBB). Kebijakan PSBB yang dibuat oleh pemerintah menimbulkan dampak kepada warga semacam penutupan sarana secara universal, seluruh pekerja melaksanakan Work From Home ( WFH), sekolah atau kampus di tutup serta diberlakukan pendidikan online dengan metode $e$-learning. (Liviana, 2020)

Dampak yang ditimbulkan dari perubahan sistem pembelajaran antara lain ketidaksiapan diri mahasiswa maupun dosen menghadapi perubahan sistem pembelajaran dari offline menjadi online hal ini membuat mahasiswa harus menghadapi kebiasaan yang baru, kurangnya interaksi antara mahasiswa dikarenakan dibatasi oleh pandemi, kendala pada jaringan internet atau saranan dan prasaranan yang tidak dimiliki, dan adanya penambahan biaya misalnya dalam membeli kuota internet, kendala dalam menggerjakan tugas dan tidak efisien dalam tenaga dan waktu yang dimiliki mahasiwa, hal ini dapat menimbulkan kurang minat dalam belajar sehingga anak menjadi stres dan juga jenuh. (Samsul, 2020)

Penelitian tentang kondisi stres dan kemampuan kognitif yang dilakukan oleh pakar dan direktur Pusat Kecerdasan Pembelajaran Terapan Seatle University John J. Medina (2008) menemukan bahwa orang yang mengalami stres memiliki pengaruh yang signifikan
C. (2021).

terhadap penurunan hasil tes kognitif, bahkan setinggi 50. Menurut penelitian (Wahyu, 2020) tentang "Stres Mahasiswa Akibat Pembelajaran Daring Selama Pandemic Covid-19 Student's Stres Impact of E-learning during Pandemic Covid-19" ditemukan bahwa 23 $(48,3 \%)$ siswa mengalami stres ringan akibat perubahan model pembelajaran online, $20(42,6 \%)$ responden, dan $4(8,5 \%)$ responden dengan stresor sedang. Stres yang dibawa oleh penggunaan online adalah karena mahasiswa tidak terbiasa menggunakannya dan bahkan mungkin pengalaman pertama mereka. Hasil penelitian (Fauziyyah, 2020) tentang "Dampak Pembelajaran Jarak Jauh Terhadap Tingkat Kecemasan Mahasiswa Fakultas Kedokteran UPN Veteran Jakarta" mengatakan sekita $88 \%$ mahasiswa mengalami kecemasan berat dan $12 \%$ mahasiwa mengalami kecemasan sedang. kemudian dari beberapa penelitian menyebutkan mengenai depresi dan kecemasan pada mahasiswa selama covid-19 di Bangladesh sekitar 87,7\% mahasiswa memiliki gejala kecemasan ringan sampai berat.(Kompas.com, 2021). Menurut (Cao et al., 2020) menjelaskan bahwa pandemi yang dapat menimbulkan masalah psikologi pada mahasiswa, hal ini karena hasil penelitian mahasiswa mengalami kecemasan berat $0,9 \%$, kecemasan sedang 2,7\% dan kecemasan ringan 21,3\%. (Andiarna, 2020)

Stres dapat mempengaruhi hasil belajar mahasiwa, karena stres dapat dengan mudah menyebabkan kebingungan dan distorsi presepsi. Distrosi ini dapat menggangu pembelajaran dengan menggurangi kemampuan berkonsentrasi, mengurangi kemampuan mengingat, dan kemampuan menghubungkan satu hal dengan yang lain. (Kaplan dan Saddock, 2005 dalam (Hasanah et al., 2020). Penelitian sebelumnya tentang "Tugas Pembelajaran Penyebab Stres Mahasiswa Selama Covid-19” (Liviana, 2020) menjelaskan bahwa hasil penelitian mahasiswa menjadi stres dikarenakan bosan dirumah $57,8 \%$, proses pembelajaran online yang mulai membosankan 55,8\%, tidak dapat bertemu dengan orang 
yang di sayangi 40,2\%, tidak dapat mengikuti pembelajaran online karena keterbatasan sinyal 37,4\%, dan tugas pembelajaran 70,29\%. Dari data diatas sangat penting sekiranya masalah ini harus segera diselesaikan karena akan berakibatkan mahasiswa tidak mampu dalam menjalin hubungan positif dengan teman-teman, kurang minat dalam belajar, kognitif menurun serta kurang paham dalam sistem pembelajaran, kurangnya saran dan prasarana, dan aktivitas yang minim. (Zahra et al., 2020)

Pembelajaran tatap muka dan online atau pembelajaran yang biasa disebut blended learning dapat dikombinasikan dengan model dan strategi pembelajaran yang inovatif hal ini mampu memberikan suasana yang nyaman, aman dan menyenangkan kepada mahasiswa, sehingga mereka selalu belajar untuk memuaskan rasa ingin tahunya, tetapi kenyataannya pada kombinasi pembelajaran ini ada yang tidak memungkinkan mahasiwa untuk mengeksplorasi atau memperoleh suasana belajar yang nyaman dikarenakan penugasan yang diberikan, sulitnya mengerjakan tugas karena ketidakefisien waktu yang diberikan antara online dan offline, kesiapan mahasiswa dalam perubahan sistem pembalajaran dan penguasaan teknologi serta sarana prasaran yang tidak mendukung membuat kesulitan belajar bagi mahasiswa maupun dosen sehingga kesehatan mental juga akan banyak mempengaruhi keadaan psikis mahasiswa (Dan et al., 2020).

Penelitian terdahulu tentang "Daya tarik pembelajaran berbasis blended learning di era revolusi 4.0" oleh (Nurlina R, 2019) didapatkan dengan kombinasi pembelajaran tatap muka, dosen dan mahassswa dapat bertemu secara langsung melalui media online yang dapat diakses kapanpun dan dimanapun. Perpaduan antara pembelajaran tatap muka dan pemeblajaran online (e-learning) dikarenakan terbatasnya waktu dan tempat mudah membuat mahasiwa merasa cepat bosan atau jenuh kemudian juga kesulitan

dalam

berkomunikasi

dalam

proses pembelajaran serta tuntutan perkembangan teknologi yang semakin luas untuk itu blended learning harus di perhatikan atau di perhitungkan. Penelitian (Mahmudah, 2020) mengatakan pendidikan online disaat ini dalam sesi penyesuaian dengan banyak hambatan semacam media, teknologi, berlangsungnya pendidikan serta dari pelajar itu sendiri. Seluruh mahasiswa tidak dapat menyesuaikan sistem pembelajaran yang baru dikarenakan membutuhkan proses dan penyesuaian terlebih dahulu pada mahasiswa dan hal ini membuat mahasiswa merasa bosan atau tidak betah, dan kurang paham dalam menangkap materi yang disampaikan dosen serta kurang minat dalam belajar. Hal tersebut menyebabkan mahasiswa lebih memilih pendidikan konvensional dari pada pembelajaran online.

Menurut (Heri, 2020) bahwa proses pembelajaran online dan tatap muka atau disebut blended learning saat ini banyak diberikan melalui perpaduan yang konvensional dan online yaitu dengan media conference, video conference, google form, dan juga di padukan dengan konvensional. Kondisi pandemi di era "new normal" membuat perubahan sistem pembelajaran secara online dan online atau lebih dikenal blended learning yang memadukan dua model pemebelajaran dalam pembelajaran ini membuat mahasiswa merasa sedikit kesulitan karena tidak semua daerah memperoleh jaringan internet, sarana prasarana yang tidak memadai, gaya pembelajaran yang baru, ketidaksesuaian waktu, dan miniminya aktivitas dikarenakan pandemi sehingga membuat mahasiswa stres atau merasa jenuh. Hal ini juga dipengaruhi oleh beberapa faktor-faktor internal maupun ekternal serta kesiapan siswa dalam beradaptasi dengan perubahan gaya belajar yang baru di era pandemi new normal.(Liviana, 2020)

Stres pada mahasiwa dapat menyebabkan mahasiswa menjadi frustasi, mudah cepat marah, menyendiri, merasa jenuh, mudah tersingung, sensitif, 
adanya konflik dengan teman-teman, dan tertekan (Muhid \& Ferdiyanto, 2020). Sehingga, apabila tidak segera diatasi maka akan menimbulkan dampak buruk bagi mahasiswa baik fisik maupun psikis, ketika masalah atau tekanan yang tidak terselesaikan dalam metode pembelajaran yang baru dpat menimbulkan respon yang kurang baik pada mahasiswa karena perubahan sistem pembelajaran dan banyak hal yang mempengaruhi untuk itu dapat ditingkatkan lagi pembelajarannya sehingga mahasiswa dapat berpikir dengan aktif dan nyaman dalam menjalani kegiatan sehari-hari. UNICEF menganjurkan dalam menghadapi stress atau kejenuhan pada mahasiswa dapat dilakukan dengan cara membuat jadwal rutin yang fleksibel misalnya membentuk kelompok belajar dengan teman menggunakan video coverance, orang tua menjadi pendengar yang baik bagi anak, memberikan motivasi atau dukungan kepada anak agar semangat dalam menjalankan pembelajaran blended learning, melakukan aktivitas yang membuat mahasiswa tidak merasa jenuh misalnya bermain game, bernyanyi atau segala aktivitas yang dapat membantu mengurangi rasa jenuh atau stres (UNICEF, 2020)

Fenomena diatas menyebabkan peneliti tertarik untuk mengambil penelitian dengan judul hubungan respon mahasiswa terhadap pembelajaran blended learning di era covid 19 dengan tingkat stres pada mahasiswa keperawatan semester 4. Hal ini membuat peneliti ingin meneliti pada responden mahasiswa semester 4 dikarenakan mahasiswa semester 4 sudah beradaptasi dengan perubahan metode pembelajaran untuk itu peneliti ingin melihat respon mahasiswa terkait keterampilan berfikir lebih dewasa, bertindak, perubahan kemandirian dalam emosional dan pengaruh sosial yang lebih kompleks terhadap pembelajaran blended learning di era covid 19. Remaja akhir pada umumnya cenderung menilai dan mengevaluasi kemampuan mereka dengan adanya perubahan pola pikir yang berubah menjadi lebih dewasa, mandiri, meningkatkan kemampuan berpikir realistis, lebih matang dalam menghadapi masalah, kemampuan mengendalikan dan menenangkan emosi, dan lebih memperhatikan tandatanda kedewasaan. Hal ini sangat berkaitan dengan pembelajaran blended learning yang diselenggarakan pada masa pandemi ini, dimana dibutuhkan kesiapan dan kemandirian mahasiswa, pola pikir yang lebih dewasa dan kritis dalam menghadapi perubahan sistem pembelajaran secara blended learning atau penggabungan sistem pembelajaran online dan offline. Perihal ini membuat peneliti tertarik untuk mengambi responden pada mahasiswa semester 4.(Febrian, 2019)

\section{METODE}

Desain penelitian ini menggunakan desai penelitian deskriptif correlation dengan pendekatan cross sectional yang mempelajari dinamika korasi antara pembelajaran blended learning di era covid 19 terhadap tingkat stres pada mahasiswa keperawatan semester 4 dengan cara pendekatan, observasi atau pengumpulan data pada satu saat. Penelitian hanya di observasi sekali saja dan pengukuran dilakukan terhadap status karakter atau variabel yang akan diteliti serta melihat apakah ada hubungan perubahan sistem pembelajaran online di era covid 19 terhadap tingkat stres pada mahasiswa semester 4. (Notoatmodjo,2012)

Sampel diambil menggunakan teknik sample total sampling dalam non probliy sampling yaitu memgambilm seluruh sample untuk digunakan penelitian dan didasarkan atas pertimbangan dan sesuai dengan kriteria inklusi dan eksklusi. Peneltian ini dilaksanakan pada tanggal 14 Juli - 23 Juli 2021 di Stikes Widyagama Husada Malang. Teknik pengumpulan data dilakukan dengan memberikan kuisioner secara online melalui google form kuisioner respon mahasiswa terhadap pembelajaran blended learning diera pandemi covid 19 dan kuisioner tingkat stres pada mahasiswa semester 4. Analisa data yang digunakan adalah 
univariat dan bivariat dengan analisa bivariat menggunakan uji Uji Chi-Square.

\section{HASIL DAN PEMBAHASAN}

Data umum karakteristik responden berdasarkan jenis kelamin dan usia. Karakteristik responden dapat dilihat pada tabel dibawah ini :

Tabel 1. Distribusi Karakteristik Responden

\section{Berdasarkan Jenis Kelamin pada Mahasiswa}

Semester 4 Stikes Widyagama Husada Malang.

\begin{tabular}{|l|l|l|l|}
\hline No & Jenis Kelamin & $\begin{array}{c}\text { Frekuensi } \\
(\mathbf{n})\end{array}$ & $\begin{array}{c}\text { Presentase } \\
(\%)\end{array}$ \\
\hline 1 & Perempuan & 43 & $86.0 \%$ \\
\hline 2 & Laki-Laki & 7 & $14.0 \%$ \\
\hline & Total & 50 & $100.0 \%$ \\
\hline
\end{tabular}

Sumber : Data penelitian 2021

Berdasarkan tabel 1 di atas, diketahui bahwa responden terbanyak dari karakterisik jenis kelamin yaitu perempuan sebesar 43 orang $(86.0 \%)$. Sedangkan, yang berjenis kelamin laki-laki sebesar 7 orang (14.0\%). Hasil penelitian dari 50 responden mayoritasnya berjenis kelamin perempuan yang mengalami tingkat stres yang lebih tinggi sebanyak 43 orang $(86.0 \%)$ dan yang berjenis kelamin laki-laki sebanyak 7 orang (14.0\%).

Penelitian sebelumnya yang dilakukan (Suwartika, 2014) mengatakan bahwa berdasakan faktor jenis kelamin yaitu perempuan sebanyak 31 orang $(40.3 \%)$ dengan tingkat stres berat yaitu 20 orang (26\%), hal tersebut dapat karena adanya beban tugas tambahan selain itu harus aktif mengikuti kegiatan proses akademik yakni civitas akademika dan juga dituntut untuk aktif dalam kegiatan berorganisasi karena keterbatasan jumlah mahasiswa yang berjenis kelamin laki-laki. Hal ini menurut Potter \& Perry (2005) jika permasalah peran tidak dapat diselesaikan dengan baik dan memiliki peran ganda serta tidak mempunyai koping yang adaptif maka permasalahan tersebut dapat menimbulkam stres pada mahasiswa. (Suwartika, 2014)

Tabel 2. Distribusi Karakteristik Responden Berdasarkan Usia pada Mahasiswa Semester 4 Stikes Widyagama Husada Malang.

Sumber: Data Penelitian 2021

\begin{tabular}{cccc}
\hline No & Usia & $\begin{array}{c}\text { Frekuensi } \\
(\mathbf{n})\end{array}$ & $\begin{array}{c}\text { Presentase } \\
(\boldsymbol{\%})\end{array}$ \\
\hline 1 & 19 Tahun & 11 & $22.0 \%$ \\
\hline 2 & 20 Tahun & 33 & $66.0 \%$ \\
\hline 3 & 21 Tahun & 6 & $12.0 \%$ \\
\hline & Total & 50 & $100.0 \%$ \\
\hline
\end{tabular}

Berdasarkan tabel 2. di atas, diketahui bahwa responden sebagian besar berusia 20 tahun sebesar 33 orang $(66.0 \%)$, Sedangkan sebagian kecil usia 21 tahun sebesar 6 oranng (12.0\%). Hasil penelitian dari 50 responden yang mengalami respon mahasiswa terhadap pembelajaran blended learning dengan tingkat stres yang tinggi banyak dialami oleh rentang 20 Tahun sebanyak 33 orang $(66.0 \%)$ pada mahasiswa semester 4. Diketahui bahwa hal ini merupakan usia mahasiswa dengan kematangan dalam mengambil keputusan dan perubahan psikologis, perkembangan sosial pada usia tersebut dapat berubah ubah atau menuju ke proses kedewasaan dan semakin tinggi tingkat usia semakin tinggi tingkat stres pada individu.(Suwartika, 2014). Menurut Agustiningsih (2019) mengemukakan bahwa hasil usia karakteristik subjek terbanyaknya yaitu usai 20 tahun yang merupakan tahap akhir perkembangan remaja, Usia tersebut merupakan usia yang sesuai disampaikan oleh Wong's \& Hockenberry (2007) yang merupakan bagian dari usia remaja akhir yaitu 18-21 tahun yang dimana pada usia tersebut perkembangan mental anak tinggi. Perkembangan mental pada usia remaja akhir membuat kemampuan remaja untuk melakukan apapun yang Media Husada Journal of Nursing Science, Volume 2, Nomor 3, November 2021 
berhubungan pada hidupnya dan lingkungannya juga meningkat. (Agustiningsih, 2019)

Tabel 3. Distribusi Responden Berdasarkn Respon Mahasiswa Terhadap Pembelajaran Blended Learning Pada Mahasiswa Keperawatan Semester 4 STIKES Widyagama Husada Malang

\begin{tabular}{|l|l|l|l|}
\hline No & $\begin{array}{l}\text { Respon } \\
\text { Mahasiswa } \\
\text { Terhadap } \\
\text { pembelajaran } \\
\text { Blended } \\
\text { Learning }\end{array}$ & $\begin{array}{c}\text { Frekuensi } \\
(\mathbf{n})\end{array}$ & $\begin{array}{c}\text { Presentase } \\
(\%)\end{array}$ \\
\hline 1 & Amat Baik & 5 & $10.0 \%$ \\
\hline 2 & Baik & 7 & $14.0 \%$ \\
\hline 3 & Cukup & 18 & $36.0 \%$ \\
\hline 4 & Kurang & 20 & $40.0 \%$ \\
\hline & Total & 50 & $100.0 \%$ \\
\hline
\end{tabular}

Sumber : Data Penelitian 2021

Berdasarkan tabel 3. diatas dapat diketahu bahwa sebagian besar responden yang kurang memiliki respon terhadap pembelajaran bleded learning yaitu sebesar 20 orang $(40.0 \%)$, sedangkan sebagian kecil memiliki respon yang amat baik sebesar 5 orang $(10.0 \%)$

Hasil penelitian ini berdasarkan respon mahasiswa terhadap pembelajaran blended learning diketahui bahwa sebagian besar memiliki respon mahasiswa yang kurang terhadap pembelajaran blended learning sebesar 20 orang $(40.0 \%)$, sedangkan sebagian kecil respon yang baik terhadap pembelajaran blended learning sebesar 5 orang (10.0\%). Data ini menunjukan bahwa sebagian besar atau banyak mahasiswa memiliki respon yang kurang terhadap pembelajaran blended learning dibandingkan dengan respon mahasiswa yang amat baik terhadap pembelajaran blended learning, hal ini juga di pengaruhi dengan perubahan pembelajaran, adaptasi lingkungan terhadap pembelajaran baru disituasi pandemi, sarana prasaran yang kurang memadai dan jaringan internet yang kadang mengalami gangguan.(Imtikhani et al., 2020).

Menurut penelitian yang dilakukan Herwanto (2020) menyatakan bahwa respon pembelajaran blended learning dimasa pandemi dapat dijadikan alternatif untuk metode pembelajaran baru dan belum bisa berjalan efektif atau masih ada hambatan sehingga kurang efektif dengan penerapan pembelajaran blended learning, kendalanya dalam koneksi internet tidak stabil (42.9\%), masalah lsitrik (22.2\%), kehabisan pulsa (17.5\%), ketidak sesuaian waktu $(9.5 \%)$ namun hanya sebagian kecil menjawab koneksi internet lancar dan tiak ada masalsah (7.9\%).(Damayanthi, 2020)

Secara teori respon diartikan sebagai reaksi, jawaban, pengaruh atau akibat dari suatu proses. Reaksi adalah segala bentuk aktivias individu yang dihasilkan oleh rangsangan, sedangkan jawabannya adalah suatu pertanyaan yang muncul, dan sebagai salah satu fungsi utama jiwa, reaksi dapat diartikan sebagai gambaran ingatan pada suatu objek yang diamati tidak berada dalam waktu pengamatan karena jika proses pengamatan berhenti yang ada hanyalah kesan.(Susiloningsih, 2018).

Menurut (Naibaho, 2016) Respon merupakan gambaran atau kesan menyenangkan respon yang muncul berupa reaksi positif maupun negatif reaksi ini selalu diberikan oleh seseorang terhadap suatu objek, peristiwa atau interaksi dengan orang lain. Beberapa penelitian menunjukan bahwa respon muncul dari proses berpikir dan memperhatikan objek.

Adanya proses ini meningkatkan kesadaran individu terhadap objek, pada tahap ini individu akan lebih memperhatikan hal-hal yanh disukainya berdasarkan pengalaman yang diperoleh dan sadar akan objek yang dihadapinya. Perhatian ini mengacu pada proses mental ketika serangkaian rangsangan menonjol dalam kesadaran akan melemah. Kemudian individu mempresepsikan suatu rangsangan dan proses 
selanjutnya adalah menyimpannya dalam memori. Proses psikologi ini biasanya disebut memori yang merupakan sistem yang sangat terstruktur yang dapat menyebabkan organism mampu merekam fakta, sederhananya memori telah melalui tiga proses yaitu merekam, menyimpan dan mengingat. Tahap akhinya individu menyimpannya dalam memori dan dijadikan pengetahuan, selanjutnya akan muncul perasaaan suka atau tidak pterhadap objek .(Sulhan, M. Hamdun., 2010)

Hasil penelitian tersebut dapat disimpulkan bahwa $40.0 \%$ dari responden memiliki respon yang kurang terhadap pembelajaran blended learning. Hal ini disebabkan karena beberapa faktor yang mempengaruhi respon responded dari faktor internal dan faktor eksternal. Faktor internal ada dalam diri individu dan untuk itu manusia memiliki tanggapan stimulus yang pengaruhi oleh jasmani dan rohanii yang apabila terganggu salah satu unsur maka hasil tanggapan akan berbeda antara satu dengan lain. Unsur psikologis atau jasmani meliputi keberdaan, cara aat indra bekerja dan bagian tertentu pada otak, kemudian pada rohani atau psikologis antara lain perasaan, akal, padangan jiwa, mental, pikiran, motivasi dan sebagainya. Sedangkan faktor ekstrernal ada pada lingkungan atau faktor psikis yang terjadi disekitar individu misalnya dalam penelitian ini fakror internet, ketersediaan sarana dan prasarana, bosan serta jenuh, masa PPKM dan ketidakefektifan selama perkuliahan di masa pandemi sehingga membuat mahasiswa menjadi kurang respon terhadap pembelajaran blended learning sehingga hal yang di pengaruhi pada respon pada suatu pembelajaran juga berkurang.(Angela A, 2018)

Tabel 4 Distribusi Responden Berdasarkan Tingkat Stres Pada Mahasiswa Keperawatan Semester 4 STIKES Widyagama Huada Malang

\begin{tabular}{|l|c|c|c|}
\hline No & Tingkat Stress & $\begin{array}{c}\text { Frekuensi } \\
(n)\end{array}$ & $\begin{array}{c}\text { Presentase } \\
(\%)\end{array}$ \\
\hline
\end{tabular}

\begin{tabular}{|l|l|l|l|}
\hline $\mathbf{1}$ & Stres Ringan & 4 & $8.0 \%$ \\
\hline $\mathbf{2}$ & Stres Sedang & 13 & $26.0 \%$ \\
\hline $\mathbf{3}$ & Stres Berat & 33 & $66.0 \%$ \\
\hline & Total & $\mathbf{5 0}$ & $\mathbf{1 0 0 . 0 \%}$ \\
\hline
\end{tabular}

Sumber : Data Penelitian 2021

Berdasarkan Tabel 4 diatas dapat di ketahui bahwa sebagian besar dari responden yang mengalami stres dengan kategori stres berat sebesar 33 orang (66.0\%), Sedangkan stres ringan sebesar 4 orang $(8.0 \%)$. Hasil Penelitian berdasarkan tingkat stres pada mahasiswa pada mahasiswa semester 4 di STIKES Widyagam Husada Malang. Sebagian besar mahasiswa mengalami stres dengan berkategori stres berat sebesar 33 mahasiswa (66.0\%), stres ringan sebesar 4 mahasiwa (8.0\%). Data ini menunjukan bahwa sebagian besar mahasiswa mengalami stres dengan berkategori stres berat. Hal ini dapat di lihat dari beberapa jawaban kuisioner mahasiswa sering merasa stres dan beberapa menjawab jarangan dan sangat jarang terhadap perilaku stres yang dialami.

Karakteristik responden berdasarkan usia mahasiswa yang banyak mengalami stres pada usia 20 tahun (66.0\%) dan jenis kelamin yang sering mengalami stres pada jenis kelamin perempuan sebanyak 43 mahasiswa (86.0\%). Pada usia dan jenis kelamin juga menjadi salah faktor yang dapat mempengaruhi tingkat stres pada mahasiswa. Menurut penelitian Hafifah (2017) menyatakan bahwa faktor stresor berdasarkan semester atau tingkat stresor yang paling banyak mengalami stres yang diterima stres besar dan berat pada semester IV dengan jumlah 27 responden (61\%) menunjukan bahwa stresor yang dialami perempuan lebih besar ketimban laki-laki karna mekanisme koping antara laki-laki dan perempuan berbeda atau dimana laki-laki mekanisme kopinya lebih berorientasi terhadap ego sehingga lebih santai menghadapi stresor sedangkan perempuan berbeda menunjukan reaksi tingkah laku dan Media Husada Journal of Nursing Science, Volume 2, Nomor 3, November 2021 
psikologisnya lebih besar.(Hafifah et al., 2017) Penelitian ini didukung oleh peneliti (Pramesti \& Harimurti, 2016) yang menyatakan bahwa tekanan atau stres yang rasakan mahasiswa dapat diakibatkan oleh bermacam faktor, hal ini berdapat berbagai penyebab yang dapat meningkatkan stres yang dirasakan mahasiswa. Awalnya mahasiswa ataupun mahasiswi harus menyesuaikan diri dengan area kampus, kemudian masalah akademis yang dimana terdapat tuntutan kuliah serta tugas yang menjadi menumpuk yang dapat meningkatkan tingkat stres secara signifikan dan juga faktor lain pada interpersonal skil, pergantian gaya hidup serta permasalah menyesuaikan diri dengan lingkungan yang baru. Secara teori individu stres terjadi karena suatu kondisi yang bisa diakibatkan oleh tuntutan fisik, lingkungan, serta suasana sosail yang tidak terkendali. Stres juga bisa memuncullkan penyakit bila tidak ditangani dan dapat mempengaruhi kehidupan sehari-hari begitu pula dengan mahasiswa hingga berakibat pada proses pembelajaran yang dijalaninya yang bisa merangsang kendala memori, penurunan konsentrasi, penuruan kemampuan dalam menyelesaikan masalah, serta dapat berperilaku negatif.

Menurut Lazarus dan Folkman (1984) stres dapat berhubungan erat dengan interaksi manusia dengan lingkungan, oleh karena itu stres dianggap berkaitan erat dengan orang serta lingkunganya yang mana dipengaruhi juga dengan kondisi pandemi saat ini dan faktor-faktor lainnya, bila tingkat stres bertambah dapat menimbulkan pikiran menjadi berantakan serta dapa menggangu kehidupan bila tidak dikontrol dengan baik. Stres juga terdapatnya dari stressor, hal ini membuat tekanan dalam pikiran melebihi kapasaitas setra kemampuan individu terancam, indikasi tekanan yang ditimbulkan ialah susah tidur, selera makan menurun, gelisah, perubahan mood yang tak tentu, serta tidak fokus untuk berpikir. Untuk itu dalam penelitian ini dipengaruhi oleh lingkungan atau faktor ekternal yang dapat mempengaruhi stres pada mahasiswa baik dan juga pada usia serta jenis kelamin pada faktor internal. (Wahyu, 2020) dalam (Gamayanti et al., 2018). Hasil penelitian tersebut dapat disimpulkan bahwa $66.0 \%$ mahasiswa mengalami stres yang berkategori tingkat stres berat. Peneliti berasumsi bahwa hal tersebut disebabkan bahwa hal ini disebabkan dari beberapa faktor internal dan faktor eksternal yang mana pada faktor internal seperti usia hal ini kerena semakin bertambah usai respon terhadap stresor yang dirasakan semakin besar atau banyak stresor yang terjadi, kemudian jenis kelamin yang membuat dalam menanggapi permasalahan psikologis atau stresor yang diterima berbeda antara laiki-laki dan perempuan. Sedangkan pada faktor ekstrenal dari lingkungan yang terjadi misalnya kondisi pandemi covid 19 sehingga dirumahkan segala aktivitas masyarakat sehingga terjadi perubahan pembelajaran.

Tabel 6 Hasil Hubungan Respon Mahasiswa Terhadap Pembelajaran Blended Learning dengan Tingkat Stres

\begin{tabular}{|c|c|c|c|c|c|c|}
\hline & & & gkat $\mathrm{S}$ & & Korelas & \\
\hline & & Stres & Stres & Stres & $\mathbf{i}$ & $\mathbf{p}$ \\
\hline & & Ring & Sedan & Berat & & \\
\hline & & an & $\mathrm{g}$ & & & \\
\hline Respon & Amat & 0 & 4 & 1 & 0.503 & 0.0 \\
\hline Mahasiswa & Baik & & & & & 0 \\
\hline Terhadap & Baik & 2 & 3 & 2 & & \\
\hline Pembelaja & Cuku & 2 & 5 & 11 & & \\
\hline ran & $\mathrm{p}$ & & & & & \\
\hline Blended & Kura & 0 & 1 & 19 & & \\
\hline Learning & ng & & & & & \\
\hline Total & & 4 & 13 & 33 & & \\
\hline
\end{tabular}

Sumber : Data Penelitian 2021 
Berdasarkan hasil dari tabel 6 diatas dapat diketahui bahwa dari 50 responden yang mengalami stres berat sebanyak 33 orang dengan respon mahasiswa terhadap pembelajaran blended learning berkategori amat baik sebanyak 1 orang, baik sebanyak 2 orang, cukup sebanyak 11 orang dan kurang sebanyak 19 orang. Sedangkan, responden yang stres sedang sebanyak 13 orang dengan respon mahasiswa terhadap pembelajaran blended learning berkategori amat baik sebanyak 4, baik sebanyak 3 orang, cukup sebanyak 5 orang, dan kurang sebanyak 1. Kemudian, pada stres ringan sebanyak 4 orang dengan respon mahasiswa terhadap pembelajaran blended learning berkategori amat baik sebanyak 0 , baik sebanyak 2 orang, cukup sebanyak 2 orang dan kurang sebanyak 0 .

Berdasarkan hasil uji statistik dari penelitian ini didapatkan p-value 0.000 (dibawah 0.005) sehingga dapat dibuktikan bahwa $\mathrm{H} 1$ dalam penelitian ini diterima atau signifikan antara respon mahasiswa terhadap pembelajaran blended learning dengan tingkat stres pada mahasiswa. Sedangkan, nilai koefesien kolerasi ditemukan 0.503 hal ini dapat menggambarkan bahwa terdapat hubungan antara kedua variabel. Hubungan pada penelitian ini berkolerasi kuat dengan nilai positif yang artinya hubungan kedua variabel searah dan semakin bagus respon yang diberikan maka semakin rendah tingkat stresnya akan tetapi dalam penelitian ini didapatkan bahwa kurangnya respon pada pembelajaran blended learning sehingga tingkat stres mahasiswa semakin tinggi.

Hasil dari tabel 6 didapatkan hasil anaalisis data menggunakan uji statistik Kendall's tau-b didapatkan bahwa hasil p-value $0.000(<0.005)$, dengan korelasi 0.503 yang berarti memiliki hubungan yang kuat dan positif antara respon mahasiswa terhadap pembelajaran blended learning diera covid 19 dengan tingkat stres pada mahasiswa semester 4. Menurut Onong (1993) dalam (Sakinah et al., 2020) menyatakan respon merupakan reaksi atau tanggapan terhadap suatu peristiwa yang terjadi, hal ini terdiri dari stimulusorganism-response yang menimbulkan efek khusus terhadap rangsangan sehingga dapat memperkirakan kesesuaian antara pesan dan reaksi. Reaksi atau respon yang ditimbulkan dapat bersifat positif maupun negatif, apabila responya positif maka tanggapan baik terhadap suatu peristiwa sebaliknya bila responnya negatif maka tanggapanya kurang baik atau tidak mengenakan dan hal ini dapat mempengaruhi dirinya secara jasmani maupun rohani.

Menurut Soerkanto (2017) menyebutkan bahwa respon atau response adalah perilaku yang merupakan akibat dari perilaku sebelumnya. Beliau juga mendefenisikan respon dalam kutipan "interaksi dengan perorangan atau kelompok masyarakat" hal ini mengandung rangsangan dan respon dalam tanggapan yang ada disekitarnya. Menurut (Khusniarti, 2010) menyatakan bahwa respon ialah istilah yang digunakan oleh psikologis untuk menerima reaksi terhadap rangsangan oleh panca indra dan diwujudkan dalam bentu perilaku yang muncul setelah adanya rangsangan. Menurut beberapa pendapat diatas dapat disimbulkan respon ialah reaksi atau tanggapan yang bersifat terbuka dan cenderung cepat atau lansung terhadap peristiwa yang terjadi, yang mana juga dipengaruhi dari dalam diri individu dan lingkungan sekitar. Sehingga dalam penelitian ini mempengaruhi respon psikologis mahasiswa dalam menghadapi rangsangan yang ada disetikar dari stres yang dihadapi dalam penerapan pembelajaran blended learning diera pandemi covid 19.

Menurut hasil penelitian (Nortvig et al., 2018) menyatakan bahwa faktor yang menyebabkan mahasiwa merasakan stres diakibatkan perubahan pembelajaran onine antara lain kurang interaksi antara mahasiwa dan dosen, jaringan yang tidak memadai, kurangnya bimbingan, ketidakhadiran dosen membuat mahasiwa kesulitan dalam proses belajar, namun hasil presetasi 
mahasiswa lebih baik.(Wahyu, 2020). Menurut peneliti

(George Saadé et al., 2017) yang mengemukakan bahwa $30 \%$ mahasiswa mengalami stres saat menggunakan metode pembelajaran online, namun hasilnya juga menunjukan bahwa sebanyak 20\% mahasiswa tidak mengalami stres saat melakukan pembelajaran tersebut karena mahasiwa tersebut sebelumnya sudah di latih dalam penggunaan model pembelajaran online. Secara teori, ada banyak faktor yang mempengaruhi tingkat stres sesorang, pada intinya stres adalah tekanan yang ditimbukan oleh interaksi antara individu dengn lingkungan, yang mempengaruhi fisik, perilaku, kognitif, dan emosional. (Dwivedi et al., 2020).

Menurut Smeltzer dan Bare (2008) dalam (Suwartika, 2014) menyatakan salah satu faktor yang dapat mempengaruhi kesehatan mahasiswa merupakan stres yang dianggap sebagai sumber stres pada kehidupan akademik. Namun, jika mahasiswa mampu mengelolah stresor ini melalui respon yang tepat dapat menciptakan kondisi adaptif yang menjaga mahasiswa tetap sehat dan menghindari mahasiswa pergi ke pusat kesehatan. Kemudian, menurut Angolla \& Ongori (2009) dalam (Suwartika, 2014) mengkonfirmasi hasil penelitian ini dapat menunjukan ketergantungan pada pengelolaan setiap individu stresnya dapat memiliki efek positif atau negatif yang diatur oleh masing-masing individu. Menurut (Mahmudah, 2020) mengatakan bahwa respon mahasiswa terhadap pembelajaran blended learning saat ini mengalami penyesuaian dengan respon yang kurang terhadap pembelajaran yang baru karena banyak hambatan semacam media, teknologi, serta proses pembelajarannya, perubahan pembelajaran ini membutuhkan proses agar dapat menyesusaikannya karna kondisi pandemi dan lingkungan membuat mahasiswa merasa kurang respon dan tangap dalam penerapan pembelajaran. Menurut (Pawicara \& Conilie, 2020) menggemukan hasil penelitiannya menunjukan bahwa mahasiswa mengalami kejenuhan karna berbagai faktor, faktor-faktornya antara lain media atau materinya kurang meranik dan penyajian materi dilakukan secara monoton sehingga respon dalam menanggapi materi kurang. Tugas yang diberikan banyak dan penjelasan materi yang kurang mendalam membuat mahasiswa salah dalam memahami materi. Oleh karena itu dalam proses pembelajaran online akan menimbulakan perasaan malas, kehilangan semangat, stres yang tinggi, seulit tidur, jenuh, dan bosan denganmateri perkuliahan. Hubungan respon mahasiswa terhadap pembelajaran blended learning diera covid 19 dengan tingkat stres dibutuhkan melakukan kegiatan yang positif dalam menjalani pembelajaran disituasi pandemi agar dapat mengatasi mekanisme koping yang baik dan respon yang dirasakan mahasiswa baik atau positif sehingga tidak menimbulkan dampak yang besar dalam psikilogis mahasiswa baik dari faktor internal maupun eksternal dan diharapkan dalam penerapan pembelajaran blended learning dapat disesuaikan dengan metode pemebelajaran yang baru sehingga lebih dalam dan dapat mendukung kesehetan mental mahasiswa dan respon yang diterima pada mahasiwa baik.

Jika dikaitkan dengan teori-teori diatas maka peneliti dapat mengambil kesimpulkan bahwa tingkat stres terhadap respon mahasiswa menunjukan bahwa mahasiswa sebagian besar mengalami stres yang meningkat dengan respon yang kurang terhadap pembelajaran blended learning diera covid-19. Tingkat stres meningkat dan respon yang kurang pada mahasiswa dipengaruhi faktor internal dan eksternal antara lain lingkungan, ketidakcukupan sumber daya yang dimiliki, kurang kesiapan dalam perubahan pembelajaran, kurangnya sarana prasaran, ketidakpahaman dalam memahami materi, kurangnya kegiatan-kegiatan positif disituasi pandemi. Sehingga diharapkan dapat menyesuaikan kegiatan-kegiatan positif yang lebih disituasi pandemi dan mekanisme koping yang baik dalam penerapan pembelajaran blended learning agar 
respon atau tanggapan yang diterima dapat meningkat dengan baik disituasi pandemi pada mahasiswa STIKES Widyagama Husada Malang.

\section{KESIMPULAN}

Dari 50 responden yang menunjukann bahwa stres terhadap pembelajaran blended learning yaitu berusia 20 tahun $(66.0 \%)$, dan banyak dialami oleh perempuan yaitu (86.0\%). Responden menunjukan respon terhadap pembelajaran blended learning dengan kategori kurang sebanyak 20 orang (40.0\%) dan tingkat stres berkategori stres berat pada mahasiswa sebanyaak 33 orang $(66.0 \%)$ respon mahasiswa terhadap pembelajaran blended learning dengan kategori kurang sebesar 20 orang (40.0\%). Hal ini menunjukan bahwa respon mahasiswa terhadap pembelajaran blended learning di era covid 19 mayoritas kurang respon terhadap pembelajaran blended learning dan pada tingkat stres pada mahasiswa semester 4 mayoritas pada stres berat. Dapat disimpulkan bahwa ada Adanya hubungan positif yang signifikan antara respon mahasiswa terhadap pembelajaran blende learning diera covid-19 dengan tingkat stres pada mahasiswa semester 4, yang ditunjukandengan nilai koefisien korelasi $\mathrm{r}=0.503$ dan $\mathrm{p}=0.000(\leq 0.05)$ sehingga hal ini dapat dilihat semakin bagus respon yang diberikan semakin rendah tingkat stresnya dan sebaliknya jika kurangnya respon yang diberikan terhadap pembelajaran blended learning maka semakin tinggi tingkat stresnya.

\section{UCAPAN TERIMA KASIH}

Terima kasih kepada Stikes Widyagama Husada Malang yang telah memberikan saya kesempatan untuk dapat melakukan penelitian terkait Hubungan Respon Mahasiswa terhadap Pembelajaran Blended Learning diera Covid 19 dengan Tingkat Stres Pada Mahasiswa Keperawatan Semester 4 di Stikes Widyagama Husada Malang.

\section{DAFTAR RUJUKAN}

Agustiningsih, N. (2019). Gambaran Stress Akademik dan Strategi Koping Pada Mahasiswa Keperawatan. Jurnal Ners Dan Kebidanan (Journal of Ners and Midwifery), 6(2), 241-250. https://doi.org/10.26699/jnk.v6i2.art.p241-250

Andiarna, F. (2020). Pengaruh Pembelajaran Daring terhadap Stres Akademik Mahasiswa Selama Pandemi Covid-19. Jurnal Psikologi, 16(2), 139. https://doi.org/10.24014/Jp.V16i2.10395

Angela A. (2018). Respon Mahasiswa Fakultas Dakwah Dan Komunikasi Uin Walisongo Semarang Terhadap Tayangan Dakwahtainment "Mari Kita Sahur" Trans Tv. New England Journal of Medicine, 372(2), 2499-2508.

http://www.ncbi.nlm.nih.gov/pubmed/7556065 \%0Ahttp://www.pubmedcentral.nih.gov/articler ender.fcgi?artid=PMC394507\%0Ahttp://dx.doi. org/10.1016/j.humpath.2017.05.005\%0Ahttps:// doi.org/10.1007/s00401-018-1825z\%0Ahttp://www.ncbi.nlm.nih.gov/pubmed/27 157931

Cao, W., Fang, Z., Hou, G., Han, M., Xu, X., Dong, J., \& Zheng, J. (2020). The psychological impact of the COVID-19 epidemic on college students in China. Psychiatry Research, 287(March), 112934.

https://doi.org/10.1016/j.psychres.2020.112934

Damayanthi, A. (2020). Efektivitas Pembelajaran Daring di Masa Pandemi Covid 19 pada Perguruan Tinggi Keagamaan Katolik. JURNAL SOSIAL : Jurnal Penelitian Ilmu-Ilmu Sosial, $21(3)$ $53-56$. http://sosial.unmermadiun.ac.id/index.php/sosia 1/article/view/61

Dan, P., Serta, P., \& Pemerintah, K. (2020). Dampak Pandemi Novel-Corona Virus Disiase ( Covid19 ) Terhadap. 6(1), 39-49. 
Dwivedi, D., Kaur, N., Shukla, S., Gandhi, A., \& Tripathi, S. (2020). Perception of stress among medical undergraduate during coronavirus disease-19 pandemic on exposure to online teaching. National Journal of Physiology, Pharmacy and Pharmacology, 10(8), 1. https://doi.org/10.5455/njppp.2020.10.0510720 2009052020

Febrian, P. A. (2019). Blended Learning Syarah: Bagaimana Penerapan dan Persepsi Mahasiswa. Jurnal Gantang, 4(2), 111-119. https://doi.org/10.31629/jg.v4i2.1560

Gamayanti, W., Mahardianisa, M., \& Syafei, I. (2018). Self Disclosure dan Tingkat Stres pada Mahasiswa yang sedang Mengerjakan Skripsi. Psympathic : Jurnal Ilmiah Psikologi, 5(1), 115130. https://doi.org/10.15575/psy.v5i1.2282

George Saadé, R., Kira, D., Mak, T., \& Nebebe, F. (2017). Anxiety \& Performance in Online Learning. Proceedings of the 2017 InSITE Conference, January, 147-157. https://doi.org/10.28945/3736

Hafifah, N., Widiani, E., \& Rahayu, W. H. (2017). Perbedaan Stres Akademik Pada Mahasiswa Program Studi Ilmu Keperawatan Berdasarkan Jenis Kelamin Di Fakultas Kesehatan Universitas Tribhuwana Tunggadewi Malang. Nursing News, 2, 220-229.

Hasanah, U., Ludiana, Immawati, \& PH, L. (2020). Gambaran Psikologis Mahasiswa Dalam Proses Pembelajaran Selama Pandemi Covid-19. Jurnal Keperawatan Jiwa, 8(3), 299-306. https://jurnal.unimus.ac.id/index.php/JKJ/article /view/5941

Heri, D. (2020). Menyiapkan Pembelajaran dalam Memasuki “ New Normal ” dengan Blended Learning. 2019, 1-9.

Ifdil, F. (2020). Kecemasan remaja pada masa pandemi
Covid -19. 6(1), 1-4.

Imtikhani et al. (2020). Peran pendampingan belajar blended learning di masa pandemi covid-19 untuk siswa sekolah dasar. https://kkn.unnes.ac.id/lapkknunnes/32004_330 8122004_6_Desa Bumiayu_20200917_185238.pdf

Khusniarti, R. (2010). Dakwah Jamaah Tabligh \& Eksistensinya Di Mata Masyarakat. http://repository.iainponorogo.ac.id/495/1/jama ah tabligh.pd

Kompas.com. (2021, January 15). Belajar Daring Bikin Stres? Ini Tiga Cara Mengatasinya Halaman all - Kompas.com.

https://edukasi.kompas.com/read/2021/01/15/09 2430971/belajar-daring-bikin-stres-ini-tigacara-mengatasinya?page $=$ all

Liviana, P. (2020). “ tugas pembelajaran ” penyebab stres mahasiswa selama pandemi covid-19. 3(2), 203-208.

Mahmudah, S. R. (2020). Pengaruh Pembelajaran Daring terhadap Psikologis Siswa Terdampak Social Distancing Akibat Covid 19. 2(2), 1-14.

Muhid, A., \& Ferdiyanto, F. (2020). Stres akademik pada siswa: Menguji peranan iklim kelas dan school well-being. Persona:Jurnal Psikologi Indonesia, 9(1), 140-156 . https://doi.org/10.30996/persona.v9i1.3523

Naibaho, M. (2016). Respon Masyarakat Terhadap Pesan Komunikasi Survei Sosial Ekonomi Nasional Pada BPS Kota Pematangsiantar. Jurnal Simbolika, 2(1).

Nortvig, A. M., Petersen, A. K., \& Balle, S. H. (2018). A literature review of the factors influencing elearning and blended learning in relation to learning outcome, student satisfaction and engagement. Electronic Journal of E-Learning, $16(1), 45-55$. 
Nurlina R. (2019). Daya Tarik pembelajran berbasis

blended learning di era revolusi 4.0. http://digilib.unimed.ac.id/37348/1/27.-Riza-

Nurlina.pdf

Pawicara, R., \& Conilie, M. (2020). Analisis Pembelajaran Daring Terhadap Kejenuhan Belajar Mahasiswa Tadris Biologi Iain Jember di Tengah Pandemi Covid-19. ALVEOLI: Jurnal Pendidikan Biologi, 1(1), 29-38.

Pramesti, N. M. G. A., \& Harimurti, R. (2016). Pengaruh penerapan model pembelajaran blended learning untuk meningkatkan aktivitas belajar siswa kelas X TKJ. It-Edu, I(02), 76-81.

https://jurnalmahasiswa.unesa.ac.id/index.php/itedu/article/view/17988

Sakinah, N., Sumijaty, S., \& Rahman, E. T. (2020). Respon Komunitas Pemuda Faiths Terhadap Kajian Khitobah Berbasis Materi Tauhid. Tabligh: Jurnal Komunikasi Dan Penyiaran Islam, 4(1), 30-44.

https://doi.org/10.15575/tabligh.v4i1.660

Samsul. (2020, July 23). Dampak Pandemi Covid-19 Bagi Mahasiswa - Perpustakaan IAIN Tulungagung. https://perpustakaan.iaintulungagung.ac.id/index.php/2020/07/23/dampa k-pandemi-covid-19-bagi-mahasiswa/\#respond

Sulhan, M. Hamdun., M. (2010). Respon masyarakat tentang pencitraan radio persada fm sebagai radio keagamaan studi pada desa Drajat kecamatan Paciran kabupaten Lamongan. 1012.

Susiloningsih, W. (2018). Respon Mahasiswa Dalam Penerapan Strategi Jurnal Refleksi Mahasiswa. Edustream: Jurnal Pendidikan Dasar, II(1), 5563.https://journal.unesa.ac.id/index.php/jpd/arti cle/view/7507

Suwartika, I. (2014). Analisi Faktor yang Berhubungan dengan Tingkat Stres Akademik Mahasiswa reguler Program Studi D III Keperawatan Cirebon Poltekkes Kemenkes Tasikmalaya. Jurnal Keperawatan Soedirman (The Soedirman Journal of Nursing), 2(1), 17-23. http://jks.fikes.unsoed.ac.id/index.php/jks/articl e/view/185/86gmbran

UNICEF. (2020, August 25). 5 ways to help keep children learning during the COVID-19 pandemic $\mid$ UNICEF. https://www.unicef.org/coronavirus/5-tipshelp-keep-children-learning-during-covid-19pandemic

Wahyu. (2020). Stres Mahasiswa Akibat Pembelajaran Daring Selama Pandemic Covid-19 Student's Stres Impact of E-learning during Pandemic Covid-19. https://aisyah.journalpress.id/index.php/jika/arti cle/downloadSuppFile/5225/106

Zahra, T., Wardhani, Y., \& Krisnani, H. (2020). Optimalisasi Peran Pengawasan Orang Tua Dalam Pelaksanaan Sekolah Onli Ne Di Masa Pandemi COVID-19 Universitas Padjadjaran. $48-59$. 